\title{
公営・改良住宅の実態調査にもとづく類型特性に関する研究 RESEARCH ON TYPOLOGICAL CHARACTERISTICS BASED ON A SURVEY OF THE ACTUAL STATE OF PUBLIC AND IMPROVEMENT HOUSING
}

\author{
石井政雄 ${ }^{*}$, 山田悟史 ${ }^{*}$, 大内宏友 ${ }^{* * *}$ \\ Masao ISHII, Satoshi YAMADA and Hirotomo OHUCHI
}

\begin{abstract}
This research aims to understand the problems occurring in each of the types of buildings and residents, based on the questionnaire survey of public housing and improvement housing that was implemented as a housing environment development project. The main indicators such as "very old buildings with single, elderly inhabitants," "housing standard," and "deteriorated housing" were first assessed by employing principal component. Then, using cluster analysis, the entire objective was divided into four types and the trend of problems for each type were analyzed. Research outcome may become reference data for the redevelopment and improvement of housing currently being implemented.
\end{abstract}

Keywords : Public Housing, Improvement Housing, Improvement Project, Typological Characteristic,

Apartment Community, Elderly Person

公営住宅，改良住宅，住環境整備事業，類型特性，団地コミュニティ，高齢者

\section{1. はじめに}

住宅地区改良事業をはじめとする住環境整備事業は、昭和 35 年 の「住宅地区改良法」施行以降、これまで約 1,900 地区において実 施され、その中心を占める昭和 40 年代に整備された大規模な団地 においては、住宅の老朽化、団地住民の高齢化、所得の上昇した世 帯の地区外転出と重なってコミュニテイバランスが崩れ、住民の自 治能力や見守り機能が低下寸る等の問題が指摘されている。このよ うな地区全体のコミュニティ活力に係る課題に対し、これまで必要 に応じて改良住宅の譲渡、福祉部局との連携強化、みなし特定公共

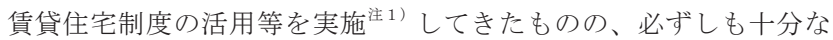
成果が得られていない状況にある。

本研究は、整備から数十年経過し、コミュニティ活力の低下など がみられる大規模な住宅団地注2) について、(1)建物特性(2)居住者・ 世帯等の特性(3)集住体において発生している問題とそれに対する対 応の内容(4)問題を解決し団地のコミュニティの活力を維持していく ために組織化された主体の有無とその活動内容を明らかにすること により、集合住宅の集住体における環境整備事業の計画課題に関す る整備指針の提示を行うことを目的とする。

なお、公営・改良住宅を対象とした既往研究には下記に示すおお よそ $3 つ$ 領域に関する研究実績があり、(1) 特定な公営住宅を対 象とし、住民参加型による既存公営住宅建替え方策を究明した小野 寺、安部らの研究 $\left.{ }^{1)} \sim 4\right)$ 、(2) 今後の公営住宅対策の課題となる外国 人居住者、高齢居住者、自治会をテーマとし、その方向性を究明し
た稲葉、長谷川、小山らの研究 ${ }^{5)}$ ９，(3)居住実態、公営住宅の再 編など、本研究の目的・項目に関連寸る内容をもつが研究対象を特 定団地とした佐藤、小山らの研究 $\left.{ }^{10)} \sim 11\right)$ 、などが挙げられる。著者 らも ${ }^{12)}$ 15)、これまで特定な団地を対象に建替事業を団地内部の問 題として隔離しようとする傾向に対して、より広範囲な構造におい て問題を把握し、解決の方途を探ることや、本研究の一環としても 数ヶ地点を対象とした事例研究を行ってきている。さらに、集合住 宅に関する研究についても超高層集合住宅の集住体を対象に研究を 行っている。地域住民の意識調查により認知特性の形成要因を分析 し、得られた要因を指標とした類型化分析から居住階の空間単位ご との環境認知について把握している。本稿は、これら一連のものと 位置づけられるが、前述の問題意識のもとで全国を研究対象とし類 型特性を明らかにした研究は少ない。以上のことから本稿では、高 齢化による問題の発生が指摘される公営住宅・改良住宅について広 範な調查を行い、現状の問題点を把握する上で主な要因とその実態 に関する類型特性の考察を行う。

\section{2. 研究概要}

\section{·調查方法}

調查方法は郵送式のアンケート調查とし、公営・改良住宅の管理 を行っている 1,666 自治体において一団としての戸数が 200 戸以上 の団地を対象に行った。調查項目は、数值で回答寸る「建物の特 性（設問 1)」「居住者の特性（設問 2)」と、記述式及び選択式で回
* (株)開発計画研究所 工修

** 立命館大学理工学部建築都市デザイン学科 助教 $\cdot$ 博士 (工学)

*** 日本大学生産工学部建築工学科 教授·工博
Development Planning Institute, Inc., M. Eng.

Assistant Prof., Dept. of Architecture and Urban Design, Ritsumeikan Univ., Dr. Eng.

Prof., Dept. of Architecture College Industrial Technology, Nihon Univ., Dr. Eng. 
表 1 アンケート回収のあった住宅の棟数及び戸数

\begin{tabular}{|c|c|c|c|c|c|}
\hline \multicolumn{2}{|c|}{ 自治体数 } & \multicolumn{4}{|c|}{ 144自治体 } \\
\hline \multicolumn{2}{|c|}{ 団地数 } & \multicolumn{4}{|c|}{ 461団地 } \\
\hline \multirow{8}{*}{$\begin{array}{l}\text { 事 } \\
\text { 業 } \\
\text { 種 } \\
\text { 別 }\end{array}$} & \multirow{2}{*}{ 公営住宅 } & 棟数 & 8,305 & & $(71.0 \%)$ \\
\hline & & 戸数 & 151,617 & 戸 & $(75.1 \%)$ \\
\hline & \multirow{2}{*}{ 改良住宅 } & 棟数 & 1,379 & 棟 & $(11.8 \%)$ \\
\hline & & 戸数 & 14,650 & 戸 & (7. $3 \%)$ \\
\hline & \multirow{2}{*}{$\begin{array}{l}\text { 公営·改良 } \\
\text { 住宅混合 }\end{array}$} & 棟数 & 2,006 & 棟 & $(17.2 \%)$ \\
\hline & & 戸数 & 35,042 & 戸 & (17. $4 \%)$ \\
\hline & \multirow{2}{*}{ 不明注 3) } & 棟数 & 12 & 棟 & $(0.1 \%)$ \\
\hline & & 戸数 & 629 & 戸 & $(0.3 \%)$ \\
\hline & \multirow{2}{*}{ 今 計 } & 棟数 & 11,690 & 棟注 4 & $(100.0 \%)$ \\
\hline & & 戸数 & 201,938 & 戸 & $(100.0 \%)$ \\
\hline
\end{tabular}

答する「団地で発生している問題 ( 設問 3-1)」「団地で発生してい る問題とそれに対する対応の内容 (設問 3-2)」「問題を解決・解消 するための自治体施策の有効性（設問 3-3)」「団地のコミュニティ 活力維持の活動主体の有無とその活動内容 (設問 3-4)」とした。 2008 年 3 月 2 日〜 17 日の期間に実施した結果、表 1 に示すように アンケート調查に回答のあった自治体は 493 (回収率 29.6\%)、うち 200 戸以上の団地のある自治体数 144 自治体、461 団地となった。 461 団地の総棟数は 11, 690 棟、総戸数 201, 938 戸、 1 団地当たり の戸数規模は 460 戸となる。公営住宅及び改良住宅の事業種別では、 前者が棟数で $79.5 \%$ 、戸数で $84.1 \%$ を占めており 注 5 、公営住宅主 体の回答結果となった。このようなアンケート回収結果や分析手法 並びに公営・改良住宅整備の目的・経緯等、下記に示す観点を踏ま え、本稿ではこの両者（公営・改良の区分）を区分することなく、「住 環境整備事業実施地区」として一体化し分析することとした。 a. 公営住宅が「公営住宅法」(昭和 26 年 6 月 ) 、改良住宅が「住 宅地区改良法」（昭和 35 年 5 月）と、それぞれ根拠法が異なるも のの、住宅の確保に特に配慮を要する人々に対して住宅の集団的建 設を促進し、低廉な家賃で賃貸することにより国民生活の安定と公 共の福祉の増進に寄与することを共通の目的としていること。

b. 一団の団地を整備する手法として、公営住宅法、住宅地区改良 法に基づく単一的手法に加え、この双方の手法を組み入れた「公営・ 改良混合型」のタイプがあり、その棟数は 2, 006 棟、戸数は 35,042 戸、 それぞれ全体の $17.2 \% 、 17.4 \%$ 占める。したがって事業種別は 異なるものの整備の範囲としては一体である団地が存在すること。

\section{·対象概要}

調查項目と単純集計の結果を対象概要として表 2 と表 3 に示す。 「建物の特性」（表 2 ）では、総住宅戸数のうち $90.2 \%$ は居住して いるが $7.9 \%$ は空屋となっている。また、総住宅戸数の $63 \%$ は昭和 54 年以前に建設されており、新耐震基準が施行（昭和 56 年）され た以前のものであり耐震性に問題がある。「建物の状態」は約 57\% が引き続き利用することが可能としているものの、約 $34 \%$ は補修 による対応が困難・大規模な修繥が必要となっている。この傾向を 要因の一つとしてバリアフリーに対する配慮が不十分とする割合が $58 \%$ と高い。なお、「入居者の募集方法」は「自治体内の居住者に 限定」している団地が $54 \%$ となっている。この場合、特定目的公 営住宅の入居制度注9) は主に高齢者向住宅として活用しているケー スが多く、制度活用自治体（約 48\%）の30\%を超える。「居住者 の特性」（表３）では、世帯主の年令が 65 才以上は全体の約 $38 \%$ を占めている。世帯では、単身世帯が $34.0 \%$ (11, 272 世帯) と最
表 2 「建物の特性」に係る設問内容と回答結果

\begin{tabular}{|c|c|c|c|c|c|c|c|c|}
\hline \multicolumn{2}{|c|}{\begin{tabular}{|lll} 
設問項目 & 結 果 \\
\end{tabular}} & \multicolumn{2}{|c|}{ 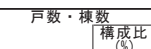 } & \multicolumn{3}{|c|}{$\begin{array}{|ll|}\text { 設問項目 } & \text { 結 } \\
\end{array}$} & \multicolumn{2}{|c|}{ 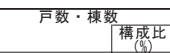 } \\
\hline \multirow{5}{*}{ 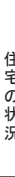 } & 住宅戸数 & 201,938 戸 & 100.0 & \multirow{4}{*}{$\begin{array}{l}\text { 構 } \\
\end{array}$} & \multicolumn{2}{|l|}{ 木造 } & 3,568戸 & 1.8 \\
\hline & 居住戸数 & 182,229 & 90.2 & & \multicolumn{2}{|l|}{ 準耐火 } & 19,570 & 9.7 \\
\hline & 空住宅 & 15,931 & 7.9 & & \multicolumn{2}{|l|}{ 耐火 } & 174,532 & 86.4 \\
\hline & 空家率 & -- & 7.9 & & \multicolumn{2}{|l|}{ 不明 } & 4,268 & 2.1 \\
\hline & 不明 & 3,778 & 1.9 & \multirow{5}{*}{\begin{tabular}{|l} 
建 \\
物 \\
猋 \\
態 \\
注8)
\end{tabular}} & \multirow{2}{*}{\multicolumn{2}{|c|}{ 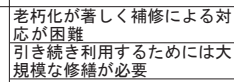 }} & 1, 796 棟 & 15.4 \\
\hline \multirow{9}{*}{$\begin{array}{l}\text { 建 } \\
\text { 設 } \\
\text { 年 } \\
\text { 度 }\end{array}$} & 昭和 39 年以前 & $8,395 \bar{F}$ & 4. 2 & & & & 2,199 & 18.8 \\
\hline & 昭和 40 年 44年 & 27,885 & 13.8 & & \multicolumn{2}{|c|}{ 引き続き利用することが可能 } & 6,622 & 56.6 \\
\hline & 昭和 45 年 49年 & 52,093 & 25.8 & & \multicolumn{2}{|l|}{ その他 } & 182 & 1.6 \\
\hline & 昭和 50 年 54年 & 38,770 & 19.2 & & \multicolumn{2}{|l|}{ 不明 } & 891 & 7.6 \\
\hline & 昭和 55 年 59 年 & 24,305 & 12.0 & \multirow{4}{*}{ 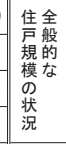 } & \multicolumn{2}{|c|}{ 世帯規模に対して狭小である } & 38 団地 & 8.1 \\
\hline & 昭和 60 年 平成 2 年 & 20,328 & 10.1 & & \multicolumn{2}{|c|}{ 世帯規模に対して適切である } & 385 & 81.9 \\
\hline & 平成3年 7年 & 11,005 & 5.4 & & \multicolumn{2}{|c|}{ 世帯規模に対して過大である } & 16 & 3.4 \\
\hline & 平成8年以降 & 13,322 & 6.6 & & \multicolumn{2}{|l|}{ 不明 } & 31 & 6.6 \\
\hline & 不明 & 5,835 & 2.9 & \multirow{4}{*}{ 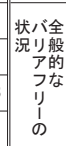 } & \multirow{3}{*}{\multicolumn{2}{|c|}{ 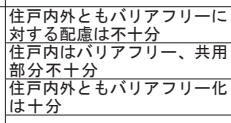 }} & 274 団地 & 58.1 \\
\hline \multirow{6}{*}{ 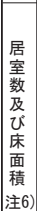 } & 2 室以下 & 15, 996戸 & 7.9 & & & & 44 & 9.3 \\
\hline & 3室 & 62,210 & 30.8 & & & & 124 & 26.3 \\
\hline & 4室 & 108,426 & 53.7 & & 不明 & & 30 & 6.4 \\
\hline & 5 室 & 12,006 & 5.9 & & \multicolumn{2}{|c|}{ 居住者にあまり利用されてい } & 22 団地 & 4. 8 \\
\hline & 不明 & 3,300 & 1.6 & 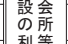 & $\begin{array}{l}\text { 息治会活重 } \\
\text { 小ない }\end{array}$ & 等には利用されて & 295 & 64.0 \\
\hline & 平畐旆甬低面積 & $53.48 \mathrm{~m}^{2}$ & - & 侽簧 & $\begin{array}{l}\text { 息治会活重 } \\
\text { ていい }\end{array}$ & 以外にも度々利用 & 85 & 18.4 \\
\hline & 2,500円未満 & 1, 956戸 & 1.1 & & 不明 & & 59 & 12.8 \\
\hline & $2,500 \mathrm{P} \sim 4,999 \mathrm{P}$ & 7,608 & 4. 1 & 入 & $\begin{array}{l}\text { 自治体内。 } \\
\text { 者等に限 }\end{array}$ & 特定の区域の居住 & 12 団地 & 2. 6 \\
\hline & $5,000 \mathrm{H} \sim 9,999 \mathrm{円}$ & 29,464 & 15.8 & 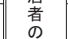 & 自治体内 $\sigma$ & 居住者等に限定 & 256 & 54.7 \\
\hline 5 & $10,000 \mathrm{P} \sim 12,499 \mathrm{P}$ & 20,218 & 10.9 & 摹 & その他 & & 186 & 39.7 \\
\hline 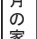 & $12,500 \mathrm{円} \sim 14,999 \mathrm{円}$ & 19,434 & 10.4 & 方 & 不明 & & 14 & 3.0 \\
\hline 賃 & $15,000 \mathrm{P} \sim 19,999 \mathrm{円}$ & 34,647 & 18.6 & & なし & & 238 団地 & 51.6 \\
\hline 注7) & $20,000 \mathrm{P} \sim 29,999 \mathrm{円}$ & 38,276 & 20.6 & 有特 & & 高齢者向住宅 & 2,036戸 & 31.3 \\
\hline & $30,000 \mathrm{H} \sim 39,999 \mathrm{円}$ & 13,279 & 7.1 & 妄曷 & & 障害者向住宅 & 1,222 & 18.8 \\
\hline & 40,000 円以上 & 11,301 & 6.1 & 数公 & 211团地 & 母子世帯向住宅 & 761 & 11.7 \\
\hline & 不明 & 9,824 & 5.3 & 䜃 & & 特別低家貢住宅 & 67 & 1.0 \\
\hline & & & & 製 & & その他 & 2,409 & 37.1 \\
\hline & & & & & 不明 & & 12 団地 & 2. 6 \\
\hline
\end{tabular}

表 3 「居住者の特性」に係る設問内容と回答結果

\begin{tabular}{|c|c|c|c|c|c|c|c|c|c|}
\hline \multicolumn{2}{|c|}{$\begin{array}{r}\text { 結 果 } \\
\text { 設問項目 }\end{array}$} & \multirow{2}{*}{$\begin{array}{l}\text { 人・世帯数 } \\
87,611 \text { 人 }\end{array}$} & \multicolumn{2}{|c|}{$\begin{array}{c}\text { 構成比 }(\%) \\
\text { 全国平均 } \\
\quad(\%) \\
\end{array}$} & \multicolumn{2}{|c|}{$\begin{array}{r}\text { 結 果 } \\
\text { 設問項目 }\end{array}$} & 人・世帯数 & \multicolumn{2}{|c|}{ 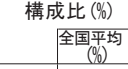 } \\
\hline 性居 & & & 43.7 & 48.8 & & 3年未满 & 14,184 世帯 & 12.7 & \multirow{4}{*}{--} \\
\hline $\begin{array}{r}\text { 別者 } \\
\text { の }\end{array}$ & & 112,876 & 56.3 & 51.2 & 居 & \begin{tabular}{|l|} 
3年以上 \\
10年未満
\end{tabular} & 32,276 & 28.9 & \\
\hline & 39歳以下 & 20,686 人 & 17.5 & 26.5 & $\mid \begin{array}{l}\text { 年 } \\
\text { 数 }\end{array}$ & 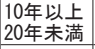 & 27,343 & 24.4 & \\
\hline & $40 \sim 64$ 歳 & 52,701 & 44.5 & 45.9 & & 20年以上 & 38,072 & 34.0 & \\
\hline & 65歳以上 & 45,108 & 38.1 & 27.6 & & $1 人$ & 52,134 世帯 & 31.7 & 29.5 \\
\hline \multirow{3}{*}{ 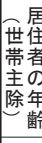 } & O $\sim 14$ 歳 & 31,337 人 & 27.6 & 28.4 & \multirow{3}{*}{ 数 } & $2 \curlywedge$ & 54,367 & 33.1 & 26.5 \\
\hline & 15 64歳 & 67,297 & 59.2 & 60.4 & & $3 人$ & 29,003 & 17.7 & 18.7 \\
\hline & 65 歳以上 & 15,081 & 13.3 & 11.2 & & 4 人 & 18,926 & 11.5 & 15.7 \\
\hline \multirow{6}{*}{\begin{tabular}{|l} 
带 \\
带 \\
類 \\
型
\end{tabular}} & 単身 & 11,272 世帯 & 34.0 & 29.5 & & $5 \curlywedge$ & 6,184 & 3.8 & 5.8 \\
\hline & 夫婦 & 5,260 & 15.9 & 19.6 & & 6人以上 & 3,613 & 2. 2 & 3.7 \\
\hline & 夫婦と子 & 8, 284 & 25.0 & 29.9 & & $\sim 10.0 \%$ & 93,345 世带 & 78.5 & \multirow{7}{*}{-} \\
\hline & 父子 & 447 & 1.3 & 1.3 & & $\sim 15.0 \%$ & 6,529 & 5. 5 & \\
\hline & 母子 & 4,887 & 14.7 & 7.1 & 収 & $\sim 20.0 \%$ & 4,351 & 3.7 & \\
\hline & その他 & 2, 997 & 9.0 & 12.7 & 分 & $\sim 25.0 \%$ & 3, 264 & 2.7 & \\
\hline \multirow{2}{*}{ 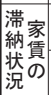 } & 滞納なし & 90,524 世 & 81.3 & \multirow{2}{*}{-} & & $\sim 40.0 \%$ & 5,037 & 4. 2 & \\
\hline & 滞納あり & 20,853 & 18.7 & & & $\sim 60.0 \%$ & 3,742 & 3.1 & \\
\hline \multicolumn{5}{|c|}{ ※全国平均值は平成17年度国勢調查結果の数值を用いた } & & $60.0 \% \sim$ & 2,679 & 2.3 & \\
\hline
\end{tabular}

も高いが母子世帯の割合も全国平均值に比べ高い。また、20 年以 上の長期居住の世帯が $34 \%$ となっている。居住世帯の収入分位注 ${ }^{10)}$ では 10\%未満の階層に居住世帯の約 $79 \%$ が占められている。また、 家賃の滞納状況では約 19\%が「滞納あり」としている。 


\section{3. 多変量解析を用いた類型特性の把握}

公営・改良住宅の類型特性を把握するため、主成分分析と類型化 分析を行う。主成分分析においては公営・改良住宅を考察する上で 重要と考えられる指標を主成分として把握する。類型化分析におい ては類型化を行い、主成分上の布置から類型特性を把握する ${ }^{\text {ì }}{ }^{11}$ 。

\section{1 主成分分析}

主成分分析は調查項目のうち数値として量的に得られた表 2 及び 表 3 のデータを対象とし、単相関、無相関、得られた定量データの 有効性の検討を経て行った。固有値と寄与率・累積寄与率を表 4 に 示す。これをみると、主成分 3 において累積寄与率 $67.72 \%$ となっ ていることから主成分 3 までを主成分として採用した。主成分 1 〜 3 の主成分負荷量を表 5 に示す。

主成分 1 ：「空住宅戸数」「昭和 54 年以前に建設された住宅戸数」 「耐火住宅戸数」「65 才以上の世帯主」「世帯人数が 1 人の世帯数」「滞 納あり戸数」「収入分位 $10 \%$ 以下の世帯数」が比較的大きな值で正 に寄与していることから、主成分 1 は「高経年建物居住の単身・ 高齢世帯」の度合いを表す軸と考えられる。

主成分 2：「一戸当たりの平均専用床面積」「平均家賃（円／戸）」 が比較的大きな值で正に寄与し、「継続利用に修繥が必要な棟数」「準 耐火住宅戸数」「世帯の平均居住年数」が比較的大きな值で負に寄 与していることから、主成分 2 は「居住水準」の度合いを表す軸と 考えられる。

主成分 3 :「木造住宅戸数」「継続利用に修繥が必要な棟数」が比 較的大きなで正に寄与していることから、主成分 3 は「不良住宅」 の度合いを表す軸と考えられる。

以上の「高経年建物居住の単身・高齢世帯」「居住水準」「不良住 宅」は、公営・改良住宅を考察する上で主要な指標と考えられる。

\section{2 類型特性}

上記の 3 主成分を用いて類型化分析を行った結果を表 6 に示す。 クラスター分析はユークリッド距離でウォード法を用いて行った。 ユークリッド距離 14.67 にて 6 種の類型が得られたが、類型 4 及び 類型 6 はサンプル数が少なく相対的にサンプルプロットのばらつき が大きかった事から、類型特性の考察は、類型 $1 \cdot 2 \cdot 3 \cdot 5$ を対 象とした。また、本稿では研究目的から選定したアンケート項目と、 公営・改良住宅整備の目的・経緯の観点から公営住宅と改良住宅を 一体として分析しているが、類型化の結果においても改良住宅を含 む団地によって類型が形成されることはなかった ${ }^{\text {注 }}{ }^{12)}$ 。類型ごとの サンプルプロット図を図 1 と図 2 に示す。

図 1 をみると主成分 1 (高経年建物居住の単身・高齢世帯の度合 い) では、類型 5 がプラスに布置されるのに対して類型 2 及び 3 は マイナスの傾向にあり、類型 1 は平均的位置づけとなっている。主 成分 2 (居住水準の度合い) では類型 2 - 5 がプラスの傾向に布置 されるのに対し類型 1 はマイナスに、類型 3 は平均的位置にある。

図 2 をみると、主成分 2 は上記した通りである。主成分 3 ( 不良 住宅の度合い）は類型 2 がプラスに、類型 3 及び 5 がマイナスの傾 向に、類型 1 が平均的位置に布置される。

以上から、類型 1 は「居住水準」の度合いが低く、「高経年建物 居住の単身・高齢世帯」、「不良住宅」の度合いが平均的という特性 をもつ類型である。類型 2 は、「居住水準」「「不良住宅」の度合い が高く、「高経年建物居住の単身・高齢世帯」の度合いが低いとい
表 4 固有値と寄与率

\begin{tabular}{|l|r|r|r|}
\hline 主成分N No. & 固有值 & \multicolumn{1}{|c|}{ 寄与率 } & 累積寄与率 \\
\hline 主成分N 0.1 & 4.992435 & $35.66 \%$ & $35.66 \%$ \\
\hline 主成分 No.2 & 2.938687 & $20.99 \%$ & $56.65 \%$ \\
\hline 主成分 No.3 & 1.550307 & $11.07 \%$ & $67.72 \%$ \\
\hline
\end{tabular}

表 5 主成分負荷量

\begin{tabular}{|c|c|c|c|}
\hline 主成分負荷量 & 主成分 $N_{0.1}$ & 主成分№.2 & 主成分 No.3 \\
\hline 空住宅戸数 & 0.689642516 & -0.262566553 & 0.324544726 \\
\hline 昭和54年以前に建設された住宅戸数 & 0.804022405 & -0.195295988 & -0.164731805 \\
\hline 木造住宅戸数 & 0.240214597 & -0.379896663 & 0.759457579 \\
\hline 準耐火住宅戸数 & 0.183792532 & -0.624217217 & -0.045595272 \\
\hline 耐火住宅戸数 & 0.845640223 & 0.475876264 & -0.093148135 \\
\hline 継続利用に修繵が必要な棟数 & 0.247506122 & -0.643507787 & 0.592985196 \\
\hline 一戸当たりの平均専用床面積 & -0.301461003 & 0.685101342 & 0.379605357 \\
\hline 平均家賃(円/戸) & -0.109468321 & 0.797196315 & 0.380218413 \\
\hline 特目住宅戸数 & 0.09436051 & 0.242531769 & 0.244417709 \\
\hline 65才以上の世帯主 & 0.903357635 & 0.205177081 & -0.090989989 \\
\hline 世帯の平均居住年数 & 0.092783787 & -0.554373436 & -0.320069336 \\
\hline 世帯人数が1人の世帯数 & 0.942975477 & 0.032234936 & 0.026529691 \\
\hline 滞納あり戸数 & 0.571076091 & 0.233599427 & -0.130614526 \\
\hline & & & \\
\hline
\end{tabular}

表 6 類型代表点の位置

\begin{tabular}{|l|r|r|r|r|}
\hline 類型No. & サンプル数 & 主成分N 0.1 & 主成分 N 0.2 & 主成分 $N 0.3$ \\
\hline 類型1 & 25 & -0.198165411 & -2.775751906 & -0.251418068 \\
\hline 類型2 & 54 & -1.418785886 & 1.418124986 & 0.697105075 \\
\hline 類型3 & 63 & -0.897514396 & -0.431863598 & -0.427591962 \\
\hline 類型4 & 10 & 6.980667002 & 0.970325241 & -0.629056745 \\
\hline 類型5 & 35 & 1.78199622 & 0.485769743 & -0.344416251 \\
\hline 類型6 & 1 & 7.663414034 & -7.629116617 & 13.10617455 \\
\hline
\end{tabular}

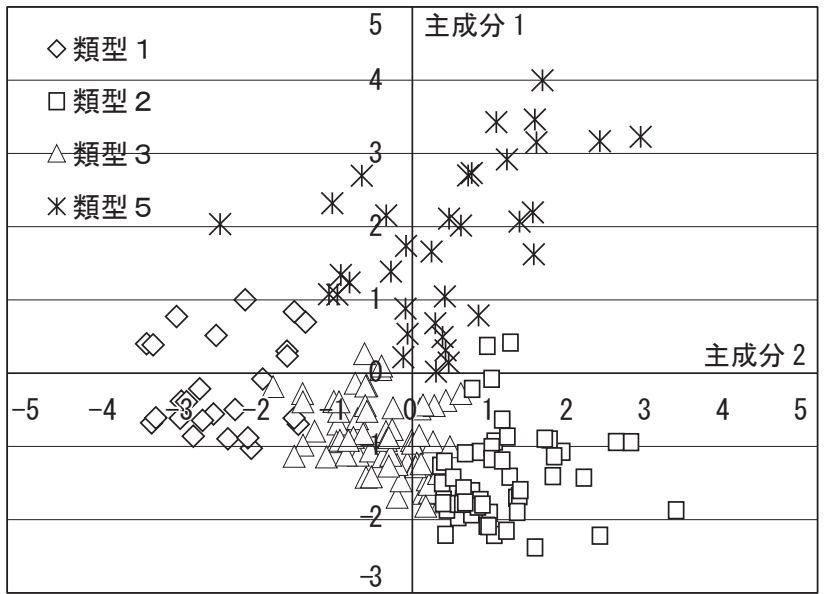

図 1 サンプルプロット図

主成分 2「居住水準」- 主成分 1「高経年建物居住の単身・高齢世帯」

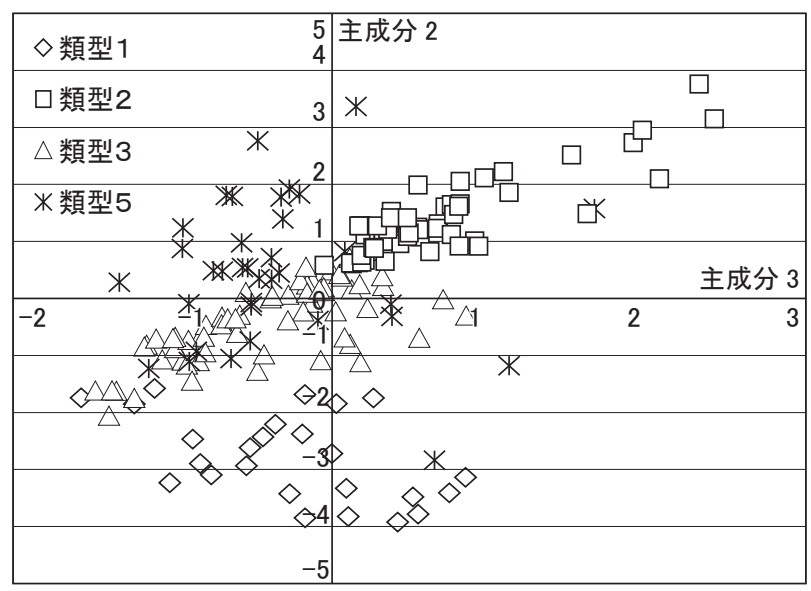

図 2 サンプルプロット図

主成分 3 「不良住宅」一主成分 2 「居住水準 
う特性をもつ類型である。類型 3 は、「高経年建物居住の単身・高 齢世帯」、「居住水準」「不良住宅」の度合いのいずれも低いという 特性をもつ類型である。類型 5 は、「高経年建物居住の単身・高齢 世帯」、「居住水準」の度合いが高く、「不良住宅」の度合が低いと いう特性をもつ類型である。

本章では以上のように公営・改良住宅の傾向として、建物及び居 住者に関する量的項目から得られる類型特性を把握した。

\section{4. 発生している問題とその対応状況に関する類型特性}

本章では前章で把握した類型特性に加え、記述式及び選択式アン ケートを用いた設問群「団地で発生している問題（設問 3-1）」、「団 地で発生している問題とそれに対する対応の内容（設問 3-2）」、「問 題を解決・解消寸るための自治体施策の有効性 ( 設問 3-3)」、「団 地のコミュニティ活力維持の活動主体の有無とその活動内容（設問 3-4)」の類型内の分布を分析し、公営・改良住宅の量的要因によっ て発生すると推測される問題とその対応内容の傾向を把握する。

\section{1 類型ごとに発生している問題}

選択式で行った「団地で発生している問題（設問 3-1）」の分析 結果を図 3 、図 4 、図 5 に示し以下に傾向を記述する。

図 3 はアンケートに用いた項目と単純集計の結果である。各問題 の発生団地数の累計 (519 団地) に対して「住宅が高齢居住者の生 活に適していない」と回答した団地数の割合は約 $14.6 \%$ 、「若年世 帯や子育て世帯の流入が少ない」(約 $10.2 \%$ )、「団地居住者の年 令構成が偏っている」（約 $10.0 \%$ )、「空屋発生が少なく、居住者 の入替わりが少ない」(約 $9.2 \%$ ) となっておりこれらの問題が発 生している団地数が高い傾向にある。また、問題グループ別では「高 齢者の生活環境」を構成する問題相互に格差が強い傾向を示すのに 対し、「コミュニティ」及び「居住者の流動性」は問題相互に格差 のない回答構成の傾向を示す。

この結果を 4 つの類型別に問題グループごとの平均指摘問題数を 図 4 に示し、問題項目ごとの類型内の平均指摘団地数を図 5 に示 す。図 4 によれば類型 1 では「 1 団地当りのコミュニティに関する 問題点」の平均指摘問題数は 1.6 と最も高く、次いで同高齢者の生 活環境が 1.5、同居住者の流動性及び生活環境がそれぞれ 0.8 となっ ている。この実態に対して図 5 に示す 4 つの問題項目ごとの類型内 の平均指摘団地数は、(1)「コミュニティに関する問題グループ」で

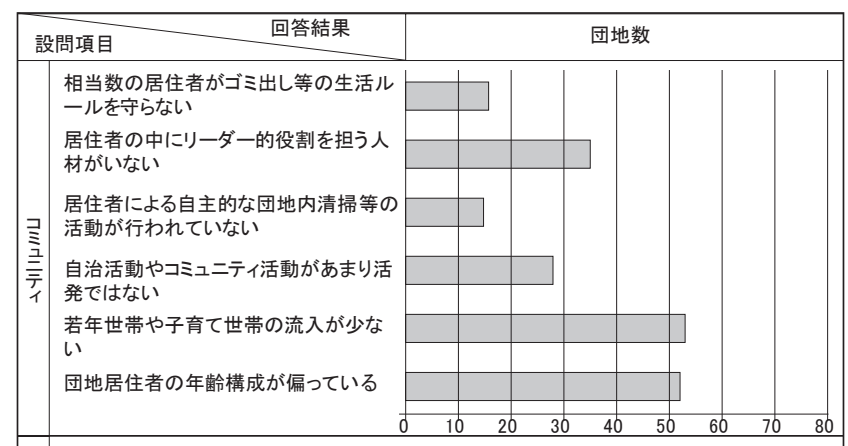

高齢居住者に引きこもりや孤立が発生 している

高 居住者やNPO等による高齢居住者に 者鍺 対する見守りが行われていない

告屋外環境や福祉施設等の整備状況か 噮高齢居住者の生活に適していない

住宅が高齢居住者の生活に適していな い
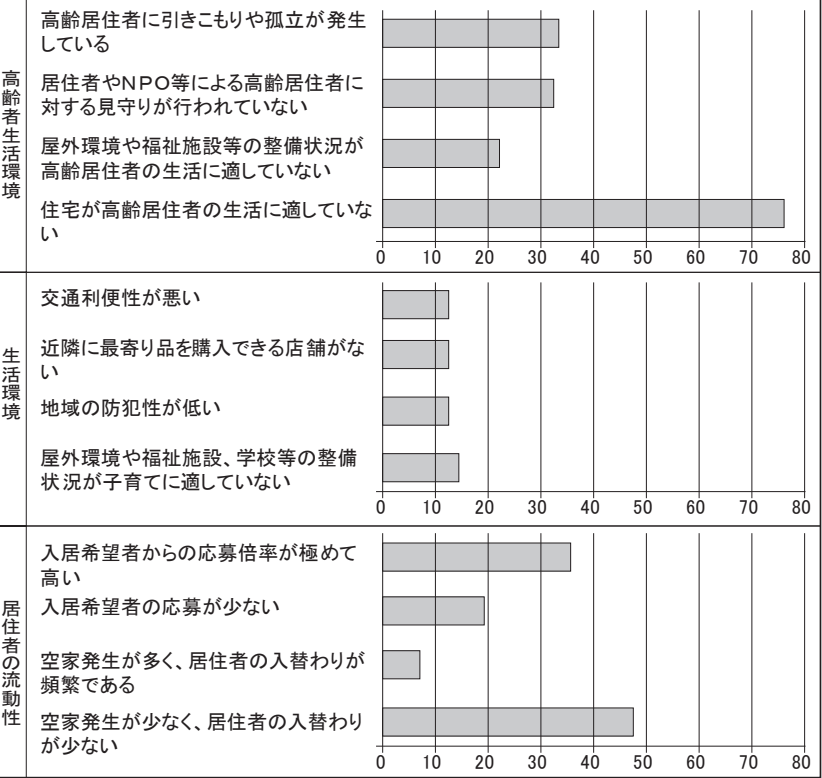

図 3 「発生している問題」に係る問題項目と回答結果

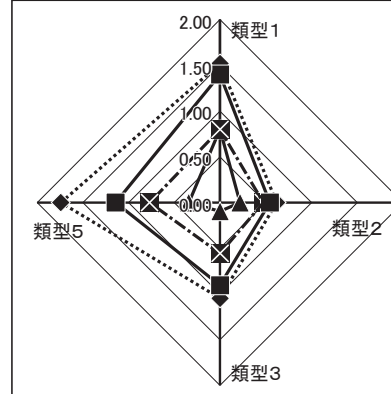

1団地当りのコミュニティに関する平

- 1 団地当りの高齢者の生活環境に 関する平均指摘問題数

1 団地当りの生活環境に関する平 均指摘問題数

1 団地当りの流動性に関する平均 指摘問題数

平均指摘問題数は、類型内の団地で発生 している問題を問題グループことに集計し、 類型を構成している団地数で除した値

図 4 問題グループごとの平均指摘問題数

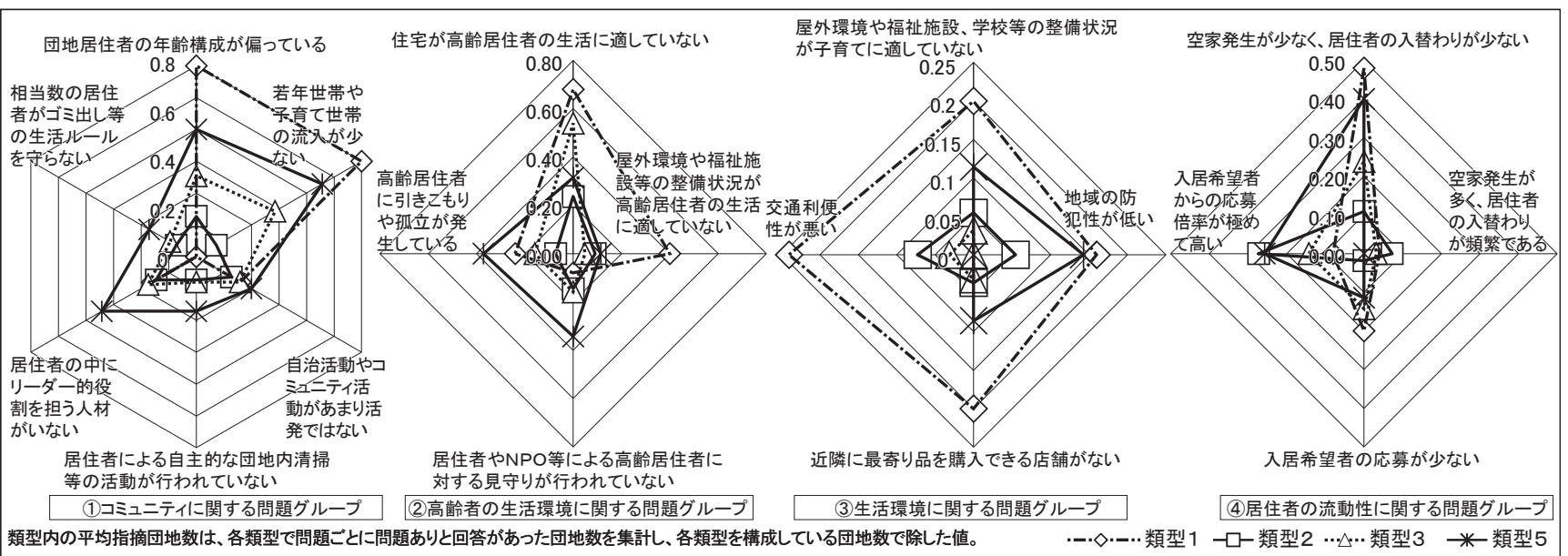

図 5 問題項目ごとの類型内の平均指摘団地数 
は、「団地居住者の年齢構成が偏っている」、「若年世帯や子育て世 帯の流入が少ない」がそれぞれ 0.8、(2)「高齢者の生活環境に関す る問題グループ」では、「住宅が高齢者の生活に適していない」が 0.7、(4)「居住者の流動性に関するグループ」では「空屋発生が少 なく、居住者の入替わりが少ない」が 0.5 となり、それぞれの問題 グループごとの主要な課題となっている。これに対し(3)「生活環境 に関する問題グループ」では、それを構成する「交通利便性が悪い」 他 4 項目の平均指摘団地数は 4 類型の中で最も高い特徴をもつ。

同様に図 4 に示寸類型 2 では、いずれの問題グループごとの平均 指摘問題数は 0.6 以下にあり、団地の居住環境は他類型に比較し相 対的に高いものと考えられる。この実態に対して図 5 に示寸 4 つの 問題項目ごとの類型内の平均指摘団地数をみると、(4)「居住者の流 動性に関するグループ」のうち「入居希望者からの応募倍率が極め て高い」が 0.2 と 4 類型の中で最も高い特性をもつ。

図 4 に示寸類型 3 では、コミュニティ及び高齢者の生活環境に関 する問題グループごとの平均指摘問題数はともに 1.0 程度である。 次いで団地の流動性が 0.6、生活環境が 0.2 となり、前二者を中心 とした問題が多い。この実態に対して図 5 に示寸 4 つの問題項目ご との類型内の平均指摘団地数では(2)「高齢者の生活環境に関する問 題グループ」のうち「住宅が高齢居住者の生活に適していない」が 0.7 と類型 1 に次ぐ問題点となっていること。また、(1)「コミュニ ティに関する問題グループ」ではそれを構成する問題点にそれぞれ 0.2 から 0.3 の平均指摘団地数にあるが、類型 1 及び 5 に次ぐ度合 いにあることなど相対的に団地の居住環境としての問題性は低い。

図 4 に示寸類型 5 では、コミュニティに関しての問題グループご との平均指摘問題数は 1.7 、次いで高齢者の生活環境が 1.2 、団地 の流動性が 0.8 、生活環境が 0.4 となっている。前三者は他 3 つの 類型の中で最も高い平均指摘問題数となっている。この実態に対し て図 5 に示す 4 つの問題項目ごとの類型内の平均指摘団地数では、 (1)「コミュニティに関する問題グループ」のうち「居住者の中に リーダー的役割を担う人材がいない」が 0.3 、「自治会活動やコミュ
ニティ活動があまり活発ではない」「相当数の居住者がゴミ出し等 の生活ルールは守らない、「居住者による自主的な団地内清掃等の 活動が行われてない」など居住者のモラル、ルールなどに係るもの が 0.2 前後に、また、(2)「高齢者の生活環境に関する問題グループ」 の中の「高齢居住者に引きこもりや孤立が発生している」、「居住者 やN P O等による高齢居住者に対寸る見守りが行われてない」など 福祉的領域に係るものが 0.2 から 0.3 に位置づけられる。しかも、 これらの問題性は問題グループ内の問題点ごとの指摘平均団地数で は他類型に比較し最も高い特徴をもつ。

以上から類型内に発生している問題について下記の傾向を把握し た。問題グループごとの平均指摘問題数は、一団地当りのコミュニ ティに関する問題点が最も高く、次いで同高齢者の生活環境、団地 の流動性の順となっている。この3つの順位はいずれの類型も同じ 傾向をもつこと。類型 1 が他類型と比較し生活環境に問題性の強い 類型であり、それには特に(3)「生活環境に関する問題グループ」の 諸項目の問題が多いことが起因していると考えられること。類型 2 での入居希望者からの応募倍率が極めて高いこと。類型 5 での (1) 「コ ミュニティに関する問題グループ」の諸項目に係る居住者のモラ ル、ルール、福祉的領域に係る問題など、量的指標によって形成さ れた類型ごとに特有な問題が発生していること。

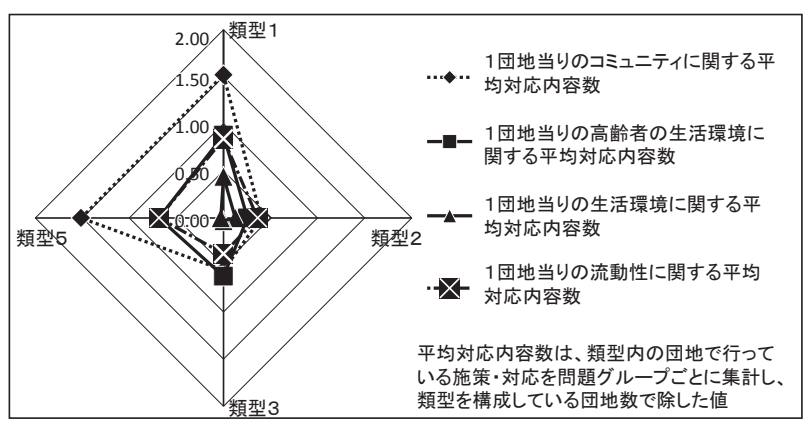

図 6 問題項目グループごとの平均対応内容数

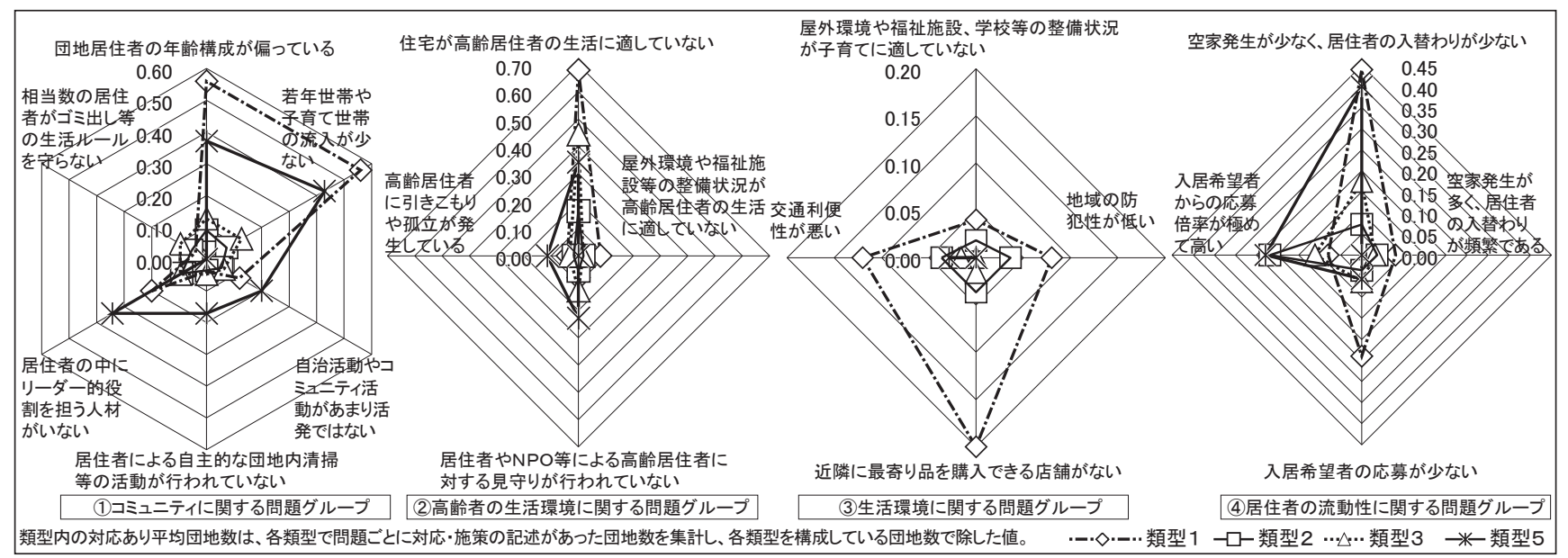

$$
\text { 図 } 7 \text { 問題項目ごとの類型内の対応あり平均団地数 }
$$

表 7 制度上の制約の有無

\begin{tabular}{|l|l|l|l|l|l|l|}
\hline & 全体 & 類型 1 & 類型 2 & 類型 3 & 類型4 & 類型 5 \\
\hline $\begin{array}{l}\text { 類型内で制約があると } \\
\text { 回答した団地割合 }\end{array}$ & $70.90 \%$ & $76.00 \%$ & $67.27 \%$ & $68.25 \%$ & $80.00 \%$ & $74.29 \%$ \\
\hline
\end{tabular}

※全体は主成分対象外も含んだ全サンプルに対する割合
表 8 コミュニティ活力維持の活動主体の有無

\begin{tabular}{|l|c|c|c|c|c|c|}
\hline & 全体 & 類型 1 & 類型 2 & 類型 3 & 類型 4 & 類型 5 \\
\hline 類型内の活動ありと & $8.68 \%$ & $12.00 \%$ & $9.09 \%$ & $15.87 \%$ & $50.00 \%$ & $28.57 \%$ \\
\hline 答した団地割合 & 8.00 & & &
\end{tabular}

※全体は主成分対象外も含んだ全サンプルに対する割合 


\section{2 類型ごとの問題対応 $\cdots$ 設問 3-2、3-3、3-4}

次に、高齢時代に対応した適切なコミュニティバランスを確保す る仕組みを検討する基本的素材として問題に対する対応の有無と対 応を行う上での制度上の制約の有無を類型ごとに把握する。「設問 3-1 において○印を付した問題を解決・解消寸るために貴自治体で はどのような対応を実施していますか。あるいは実施する予定です か。その内容について記入してください。（設問 3-2)」とする設問 について問題項目グループごとの平均対応内容数を図 6 に。問題項 目ごとの類型内対応あり平均団地数を図 7 に示す。また、「問題を 解決・解消寸るための自治体施策の有効性（設問 3-3）」において「制 約あり」と回答した類型内の団地割合を類型ごとに示したものが表 7 である。さらに、「問題を解決し、団地のコミュニティの活力を 維持するために、団地内外居住者の方々の活動や、N P O 法人等を 組織化し、活動しているケースはありますか。（「設問 3-4）」にお いて「活動有り」と回答した類型内の団地割合を示したものが表 8 である。以下に分析結果を記述する。

図 6 に示寸類型 1 での問題項目グループごとの平均対応内容数 は、一団地当りのコミュニティに関する問題点への対応が 1.5、次 いで、高齢者の生活環境及び団地の流動性が 1.0 程度、生活環境が 0.5 となっている。これを先の問題グループごとの平均指摘問題数 （図 4) の特性と比較すると高齢者の生活環境及び生活環境の領域 において平均対応内容数は減少している。この要因として図 7 の (1) 「高齢者の生活環境に関する問題グループ」での「高齢居住者に引 きこもりや孤立が発生している」、「屋外環境や福祉施設等の整備状 況が高齢居住者の生活に適していない」ままた、(3)「生活環境に関 するグループ」では「屋外環境や福祉施設、学校等の整備状況が子 育てに適していない」などの問題項目ごとの類型内対応あり平均団 地数が $0.0 \sim 0.05$ と低く十分な対応がなされていないことに起因 していると考えられる。

同様に図 6 に示寸類型 2 はいずれの問題項目グループごとの平均 対応内容数は 0.5 未満である。これを図 4 の特性と比較するとその 対応への特徴的動向は示されていない。

図 6 に示寸類例 3 では問題項目グループごとの平均対応内容数は 高齢者の生活環境、コミュニティ、団地の流動性が 0.6 前後にある。 これを図 4 の特性と比較すると、コミュニティ及び高齢者の生活環 境の平均対応内容数 (0.6 前後) は減少している。これは(1)「コミュ ニティに関する問題グループ」のうち「団地居住者の年齢構成が偏っ ている」、若年世帯や子育て世帯の流入が少ない」こと。また、(2)「高 齢者の生活環境に関する問題グループ」のうち「高齢居住者の引き こもりや孤立が発生している」、「屋外環境や福祉施設等の整備状況 が高齢居住者の生活に適していない」などの問題項目ごとの類型内 対応あり平均団地数が低いためと考えられる。

図 6 に示寸類型 5 では問題項目グループごとの平均内容数はコ ミュニティが 1.5、高齢者の生活環境及び団地の流動性がともに 0.7 となっている。これを図 4 の特性と比較すると特に高齢者の生活環 境や生活環境の領域において平均対応内容数は減少している。この 要因として図 7 の (2)「高齢者の生活環境に関寸る問題グループ」の 領域では、「高齢居住者に引きこもりや孤立が発生している」、「居 住者やN P O等らよる高齢居住者に対する見守りが行われてない」 が、(3)「生活環境に関する問題グループ」の領域では「地域の防犯
性が低い」、屋外環境や福祉施設、学校等の整備状況が子育てに適 していない」などの問題項目ごとの対応あり平均団地数が低いため と考えられる。

以上のことから類型ごとの問題対応 (図 6、図 7 ) について下記 の傾向を把握した。相対的に各類型とも一団地当りの高齢者の生活 環境に関する平均対応内容数は低く、この面での対応が十分ではな いこと。この要因として、類型 1 及び 5 の同問題に対して対応あり 平均団地数が少ないこと。その問題の内容は図 7 の (2)「高齢者の生 活環境に関寸る問題グループ」に示すように「高齢居住者に引きこ もりや孤立が発生している」、「居住者やN P O等による高齢居住者 に対する見守りが行われてない」など福祉的対応の必要性が高いも のが主体であること。また(3)「生活環境に関する問題グループ」に 関する問題項目ごとの類型内の平均指摘団地数 (図 5 ) では他類型 に比較し相対的に対応あり団地数は低い。この背景として、団地が 対応の方向性を示すことが難しい「交通の利便性」など団地のおか れている立地環境そのものにあること。

次に問 3-4の設問に対して、「十分と考える」と答えた自治体数 はアンケート回答全自治体数中 97 団地、「十分とはいえない。不十 分である。とした自治体数 160 、「不明」は 204 となった。また、上 記で『十分とはいえない。不十分である。』とした自治体ではどの ような制約が存在するのか」との設問に対して 92 の団地から具体 な制約が示された、提示された中で最も多かったものは「建て替え、 改善・改修に要する事業費の予算化」。次いで「入居者資格」、「住 宅施策と福祉施策の有機的連携」などが指摘された。このような動 向を類型別に示したものが表 7 である。全体で $70.9 \%$ の団地が制 約ありとしているが類型 4 では $80 \%$ 、類型 1 では $76 \%$ 、類型 5 で $74.2 \%$ と、この 3 つの類型が全体の比率を上回っている。これは居 住水準の向上や高経年建物に居住している単身・高齢世帯の増加傾 向とそれらの対応がかかる実態を示寸背景にあると考えられる。

更に問 3-4の設問に対して活動主体が「ある」と答えた団地はア ンケート回答全自治体数中 40 。一方、「なし」としたものは 421 で あり、その組織化率は $8.7 \%$ に止まっている。なお、「ある」とし た活動主体の多くは、「団地居住者を主体とした組織」一 -33 団地、 82. $4 \%$ 一であり、自治会活動を中心としている。これに対し、「外 部組織による活動」を組織化している団地は 7 団地 (17.6\%) となっ ている。このような動向を類型別に示したものが表 8 である。類型 4 では $50 \%$ が。類型 5 では約 $28.6 \%$ が、類型 3 では約 $15.9 \%$ がコ ミュニティ活力維持の活動主体を有している。これら類型は前掲図 4 に示した特にコミュニティ及び高齢者の生活環境に関する問題が 強く指摘される傾向にあり、この対応方向の具体的手段として組織 化されたものと考えられる。

\section{5.まとめ}

本稿はこれまで主に個別的、現象的に指摘されてきた公営住宅・ 改良住宅の現状や問題とその対応について広範なアンケート調查を 行い、現状の問題点を把握する上で主な要因と実態に関する類型特 性を考察したものである。成果を下記にまとめる。

(1)公営・改良住宅の建物と居住者に関わるアンケート調查結果を 分析し、類型特性を把握する上で主となる指標として「高経年建物 居住の単身・高齢世帯」、「居住水準」「不良住宅」を把握した。 
(2)上記 3 指標によって公営・改良住宅を類型化し 4 類型を得た。 ・類型 1 :「居住水準」の度合いが低く、「高経年建物居住の単身・ 高齢世帯」「不良住宅」の度合いが平均的特性をもつ類型。

- 類型 2 ：「居住水準」「不良住宅」の度合いが高く、「高経年建物 居住の単身・高齢世帯」の度合いが低い特性をもつ類型。

・類型 $3: 3$ つの指標いずれもが低い特性をもつ類型。

- 類型 5 ：「高経年建物居住の単身・高齢世帯」、「居住水準」の度 合いが高く、「不良住宅」の度合いが低い特性をもつ類型。

(3)量的項目による類型ごとに、発生している問題、問題の発生要 因及び対応内容、施策・対応の有効性の認識、コミュニティ活動主 体の有無とその活動を分析した。類型 1 の数量的特性をもつ公営・ 改良住宅は他 3 類型に比較し、建物及び居住者双方において問題々 対応の多様さと度合いが高く、その改善に対する制度上の制約も多 い。また、高齢者の生活環境を主に生活環境に対する問題への対応 が弱いが、これには「交通利便性が悪い」などの団地の置かれてい る外的環境条件を含んだ問題が関連していると考えられる。類型 2 は、4 類型の中で相対的に問題の多様さと各項目に対する度合いは 低い。この事を反映して制度上の制約やコミュニティ活力維持の活 動主体の組織化率は最も低いものとなっている。又、問題に対する 対応も特徵的動向はみられない。類型 3 は、類型 1 と傾向が類似し ており問題と対応の多様さと度合いが高いが、生活環境に関する問 題の多様さと度合いは比較的低い。対応としてはコミュニティに関 寸る問題への対応がやや弱い。類型 5 は、コミュニティに関する問 題の多様さと度合いが高く、対応としてコミュニティ活力維持の活 動主体の組織化率が他類型に対し最も高くなっている。しかし建物 として高齢者の生活環境に対する問題の対応が十分とは言えない。

本稿では、以上のように公営・改良住宅の建物及び居住者に関す る指標から形成された類型ごとに発生している問題とその対応状況 を分析し、公営住宅・改良住宅の類型特性・計画課題を把握した。 これらは行政が改善案を策定する際の基礎的資料として利用が期待 される。また、量的項目から発生する可能性のある問題の推測など、 計画時の基礎的資料としての利用も可能となった。一方で、公営・ 改良住宅それぞれの特性に関する詳細な考察については、本稿で用 いている指標に、「住環境整備事業実施地区」の計画課題の特性把 握を規定する要因と考えられる地域特性（地域圈域における大都市 圈之地方圈の区分、中心市街地内立地之郊外立地、都市立地之町村 立地など）等の詳細な指標を加えより小さな枠組みで分析を行う必 要があると考えられるため、この点を今後の研究課題とする。今後 は、公営・改良住宅の計画課題把握の視点の一つと考えられる立地 地域特性などについて解析を深めるとともに、地域ごとに実証的研 究を重称、より実践的な集合住宅の集住体における環境整備の指針 を提示する予定である。

\section{謝辞}

本論の調查は国土交通省からの委託研究「住環境整備事業実施地 区におけるコミュニティ活力維持向上方策検討調查」として行った ものであり、成果活用にご承諾を頂きました。記して深謝を表する。

\section{注}

注 1 ）「公共貨貸住宅団地における高齢時代に対応した適切なコミュニティ バランスの確保等について」（国土交通省住環境整備室：平成 19 年度全
国住環境整備事業推進協議会資料）において、10 の施策が示されている。 注 2 ) 住環境整備事業実施地区の平均建設戸数は約 100 戸であり、一団とし ての戸数が、この倍の 200 戸以上の公営・改良住宅を「大規模な住宅団地」 と位置づけ、これを研究対象とした。

注 3 ) 本稿の基礎となった「アンケート調査」における設問項目の中で事業 種別（公営住宅法、住宅地区改良法の別）とそれぞれの棟数、戸数を記入 することになっている。しかし、愛知県内都市の 2 つの団地において市の 担当課から確認不能との回答を得たため「不明」とした。

注 4 ) 公営住宅と改良住宅を合算しているものが 12 棟あるため総棟数は 8,305 棟 $+1,379$ 棟 $+2,006$ 棟 +12 棟 -12 棟 $=11,690$ 棟となる。

注 5 ) 棟数で $79.5 \%$ 、戸数で $84.1 \%$ は、表 1 の中の公営住宅棟数、戸数に公 営・改良住宅混合のうち公営住宅分それぞれ (988 棟、18, 133 戸) を加え、 合計数で除した割合。

注 6 )「居室及び床面積」における居室とは「居間、台所、寝室」とした。

注 7 ）「一ヶ月家賃」家賃の減免措置を受けている世帯については減免後の 家賃で戸数を記入してもらった。

注 8 )「建物の状態」は担当者の目視による判断で評価した。

注 9 ) 昭和 45 年度の公営住宅事業等補助要領の第十八に基づき、公営住宅 建設事業のうち特 別の取り扱いをする公営住宅をいう。母子世帯向公営 住宅、老人世帯向公営住宅、炭鉱離職者向公営住宅、特別低家賃公営住宅、 引揚者公営住宅、心身障害者向公営住宅、農山漁村向公営住宅、集落再編 成向公営住宅を「特定目的公営住宅」といい、住宅困穹度が特に高い者に 対する社会福祉を増進することを目的とするものである。原則として一般 の公営住宅の中で上記の特定の目的のために一定の枠を設けて、募集及び 入居の取扱いを行う入居制度をいう。

注 10 ) 総務省が実施した全国貯蓄動向調査の結果に基づいて、全世帯を収 入順位に並心゙、各世帯が下から何％の範囲に位置しているかを示した数值 をいう。

注 11 ）分析方法の選定においては、量的項目と質的項目を一つの多変量解 析として取り扱う数量化III類も試行したが、質的項目を数量化軸として数 量化することが困難だったため量的把握の主成分分析に基づき類型化を行 い、類型毎の質的項目の集計を行う。という手順により傾向を把握する方 法を選択した。この選択により量的項目と質的項目の関係性を統計学的に 明示することは出来ていないが、類型ごとの質的項目の差異の大きさから 量的項目により質的項目が生じていると解釈した。

注 12 ) 類型化分析の対象となった改良住宅を含む団地の $13.33 \%$ が類型 1 、 $22.22 \%$ が類型 2 、 $31.11 \%$ が類型 3 、 $6.67 \%$ が類型 4 、 $24.44 \%$ が類型 5 、 $2.22 \%$ が類型 6 に分布していた。また、改良住宅を含む団地の類型内の割 合は、類型 1 が $24.00 \%$ 、類型 2 が $18.52 \%$ 、類型 3 が $22.22 \%$ 、類型 4 が $30.00 \%$ 、類型 5 が $31.43 \%$ 、類型 6 が $100 \%$ （類型 6 はサンプル数が 1) であった。

\section{参考文献}

1）小野寺一成：住み手参加型改良住宅と従来型改良住宅におけるコミュ ニティの特性に関する研究一北九州市北方地区において建設された改 良住宅の住まい方比較一, 日本都市計画学会都市計画論文集, No. 383, pp. 253-258, 2003. 10

2）小野寺一成：住民参加型方式による団地統廃合を含む公営住宅の建替え に関寸る考察一北九州市 I 地区で行われた建替え事業を事例として一，日 本都市計画学会都市計画論文集, No. 43-2, pp. 65-72, 2006. 10

3) 小野寺一成, 安部聡子: 団地統廃合を含む公営住宅再生マスタープラン における住民参加の取り組みに関する研究一北九州市同和向け市営住宅活 用計画策定及び建替え事業を事例として一，日本建築学会住宅系研究報告 会論文集，第 1 号，pp. 93-102, 2006. 12

4）小野寺一成, 安部聡子：住民参加方式による多数団地統廃合を伴う公営 住宅建替えの取り組みに関寸る考察一北九州市における 3 つの公営住宅 建替え事業を通して一，日本建築学会住宅系研究報告会論文集，第 2 号， pp. 205-213, 2007. 12

5）稲葉佳子他 5 名：公営住宅および都市再生機構の賃貸住宅における外国 人居住に関寸る研究, 一外国人居住への取組みが行われる 10 団地を対象 一日本建築学会計画系論文集 VOL75 N0656, pp. 2397-2406, 2010. 10

6) 稲葉佳子：公営住宅における外国人居住の実態に関寸る研究, 日本都市 計画学会都市計画論文集, No. 43-1, pp. 66-72, 2008.4

7) 都筑くるみ：エスニック・コミュニティの形成と共生一豊田市 $\mathrm{H}$ 団地の 近年の展開から一，日本都市社会学会年報, 16 号, pp. $89 \sim 102,1998$

8) 谷武, 三宅醇：公営住宅居住者の相互扶助活動及び清掃活動に対する意 
識の研究, 第 37 回日本都市計画学会学術研究論文集, pp. 367-372, 2002. 10

9）長谷川雅浩, 花岡佳秀, 黒沢和孝：北海道の公営住宅における高齢者

居住支援施策に関する調査研究日本建築学会計画系論文集, VOL. 76

N0. 659, pp. 131-138, 2011. 1

10）佐藤由美：人口減少が進む公営住宅地区の居住者やコミュニティの変化 ーニュータウンの公営住宅居住者の居住実態, 日本都市計画学会都市計画 論文集 , No. 44-3, pp. 709-714，2009. 10

11）小山雄資, 吉田友彦：転居の可能性からみた廃止・削減を伴う公営住宅 の再編に関する研究一香川県営住宅を事例として一，日本都市計画学会都 市計画論文集 No. 42-3, pp. 211-216, 2007. 10

12）山田悟史, 三沢浩二, 大内宏友 : Study of Environmental Recognition of Super High-rise Housing Residents, Journal of Asian Architecture and Building Engineering, Vol. 4, No. 2, pp. 407-413, 2005. 11

13）山田悟史，大内宏友：超高層住宅の集住体における居住者の環 境認知に関する研究, 日本建築学会計画系論文集, VOL. 73N0.630, pp. $1749-1757,2008.8$

14）和歌山県御坊市 : 御坊市都市構造の変容における公営（改良を含む）住 宅の問題点と今後の課題, 1997

15）和歌山県御坊市：御坊市島団地改善事業に関する意識調査報告書 2001

（2012年 1 月10日原稿受理，2012年 7 月17日採用決定） 